\title{
The generic revision of the Reussellids (Foraminiferida)
}

\author{
STEFAN A. REVETS \\ Koninklijk Belgisch Instituut voor Natuurwetenschappen, Dept. of Palaeontology, Vautierstraat 29, B 1040 Brussels, Belgium
}

\begin{abstract}
The study of the apertural complex in the type species of the reussellid genera leads to a reassessment of the classification of these taxa. The genus Reussella has so many characteristics in common with Bulimina that it is reclassified in the Buliminidae. The family Trimosinidae is retained and redescribed to contain the genera Trimosina, Mimosina and Fijiella only. Pyramidina is retained in the Turrilinidae on account of the praebulimine toothplate.

The absence of an internal toothplate and the very un-bulimine apertural face in Bifarinella, Chrysalidinella, Cifellia, Finlayina, Orthocerina, Pavonina and Valvohifarina species is the main argument to remove these genera from the Buliminacea and reclassify them in the superfamily Pavoninacea herein proposed.

The genus Orthocerina d'Orbigny, 1839 is reinstated and shown to be closely related to Chrysalidinella and Cifellia.

The genus Compressigerina is reclassified in the Uvigerinidae, close to Trifarina because of the presence of an apertural neck with toothplate.
\end{abstract}

\section{INTRODUCTION}

The genus Reussella was created by Schwager (1877) (under the preoccupied name Reussia), for high trochospiral Foraminifera easily distinguished from other forms by a remarkable triangular, almost pyramidal form, with Verneuilina spinulosa Reuss, 1850 as the type species. Although some years passed before the genus became generally accepted, it was finally incorporated in the systematic schemes, always more or less closely allied to Bulimina.

Cushman (1927) created a separate subfamily for Reussia, changing its name to Reussellinae when the synonymy of Reussia was shown (Cushman, 1933). Throughout his publications he maintained the Reussellinae as a distinct subfamily in the Buliminidae (Cushman, 1948). In 1929, Cushman discussed the position of some of the reussellid genera, including Chrysalidinella Schubert, 1907, Trimosina Cushman, 1927 and Mimosina Millett, 1900. Reussella was described as a development of Bulimina, differing by being triangular but with the same kind of aperture.

Galloway (1933) proposed the name Reussella to replace the preoccupied Reussia and classified it in the Turrilininae, Buliminidae. It was kept separate from the Bulimininae, partly on account of the absence of 'an internal ribbon or pillar' as present in Bulimina (Galloway, 1933, p.357).

The restudy of all known reussellid taxa by Cushman (1945) resulted in redescriptions and a systematic arrangement which set the scene for all subsequent classifications. He classified Reussella, Trimosina, Mimosina, Paronina and Chrysalidinella in the Reussellinae, Buliminidae.

Despite the thorough study of the Bulimina, Uvigerina and
Bolivina-like taxa, Hofker (1951) devoted little attention to Reussella. He described and briefly discussed two new species and classified Reussella in the Buliminidae, discussed the status of Chrysalidina, and erected Valvopavonina and Valvohifarina. Later, he discussed in great detail the relation between the different, for the Cretaceous important, buliminid genera (Hofker, 1957). He concluded that Reussella showed distinct affinities to Praebulimina and Bulimina, but regarded Pyramidina Brotzen. 1948 as nothing but an ontogenetic development of Reussella.

Loeblich \& Tappan (1964) classified Reussella in the Pavonininae, reducing the Reussellinae to synonymy. They figured two specimens from the Vienna Basin and reproduced Hofker's drawing (Hofker, 1951, p. 143) of the toothplate of Reussella spinulosa. Besides Reussella, they included Paronina, Acostina, Chrysalidinella, the synonymised Chrysalidinoides. Fijiella, Mimosina, Trimosina, Tubulogenerina and Valvobifarina in the Pavonininae. It was mentioned in passing that the more primitive, true toothplate-bearing forms might be separately classified in the Reussellinae, while the more advanced forms would be kept in the Pavonininae (Loeblich \& Tappan, 1964. p.562).

Haynes (1981) incorporated the proposals by Loeblich \& Tappan, 1964 concerning the reussellids without discussion.

In their latest classification, Loeblich \& Tappan (1987) presented a considerable number of changes. For the Buliminacea, they propose the recognition of the Reussellidae alongside the Siphogenerinoididae, Buliminidae, Buliminellidae, Uvigerinidac, Trimosinidae, Pavoninidae and Millettiidae. They reduced the Reussellidae to include Reussella, Acostinarysalidinella. Compressigerina, Fijiella and Valvohifarina only. Mimosina and 
Trimosina are the sole genera in the Trimosinidae, while Pavonina, Bifarinella and Finlayina make up the Pavoninidae.

The instability in the classification of the Reussellidae sensu lato indicates the need for a detailed study of the taxa in question, in order to obtain all the necessary comparative data afresh.

\section{SYSTEMATIC DESCRIPTIONS}

Order Foraminiferida Eichwald, 1835

Suborder Rotaliina Lankester, 1885

Superfamily Buliminacea Jones, 1875

Family Buliminidae Jones, 1875

1875 Buliminida Jones, in Griffith \& Henfrey: 320

1927 Reussiinae Cushman: 68, nom. rej.

1933 Reussellinae Cushman: 223, nom. nov.

Type genus. Bulimina d'Orbigny, 1826

Type species. Bulimina marginata d'Orbigny, 1826

Genus Reussella Galloway, 1933

1877 Reussia Schwager, non McCoy, 1854: 26, fig.66, nom. rej.

1933 Reussella Galloway: 360, nom. nov.

Type species. Verneuilina spinulosa Reuss, 1850, original designation.

Reussella spinulosa (Reuss, 1850)

(Pl.1, figs 1-4)

1850 Verneuilina spinulosa Reuss: 374, pl.47, fig. 12

1933 Reussella spinulosa (Reuss); Galloway: 360 , pl.33, fig. 4

1964 Reussella spinulosa (Reuss); Loeblich \& Tappan: 563, fig.3 only

Types. Syntypes are probably present in the Naturhistorisches Museum Wien.

Type locality. Near Grinzing, Vienna, Austria: Badener Tegl, Badenian.

Material examined. Topotypes, courtesy H.J. Hansen.

Description. Test free, pyramidal, sharply triangular in crosssection, regularly increasing in size, 4 whorls, triserial; chambers low tetrahedral, wider than high, edges rather sharp, may slightly overhang the previous whorl, marked by a short spine at the very edge, in regular series, almost flush with the surface; intercameral sutures arched, spiral suture almost straight, distinct; aperture central at the apex of the test, apertural face almost terminal, formed by the top of the two previous chambers and for $1 / 3$ by the ultimate chamber, aperture a large elliptical opening lying along the basal suture, bordered by a low lip which descends into the lumen to form the top of the toothplate; toothplate an elegant thin plate with a free, curved border, fuses with the foraminal lip at its topmost, peripheral side; wall calcareous, optically distinctly radial, distinctly perforate, with larger pores tending to seam the sutures.

Remarks. Reussella differs from Bulimina in the pronounced angularity of the test; the chambers are tetrahedral rather than spherical and the aperture is more ovate and oriented in a Turrilina-like fashion. Although the preservational state of the available topotypes hinders critical observation of the relation between toothplate and foramen, the attachment seems to be intermediary between the very simple turriline and more extensive bulimine one. Observations of modern Reussella species show that most have a toothplate more akin to Bulimina, rather than Turrilina.

The study of material from the Vienna Basin shows that more than one species of Reussella is present in the Badenian. A revision of the genus is clearly needed to clarify the taxonomic status of most of its species.

According to F. Rögl, the Reuss collection is present in the Naturhistorisches Museum Wien. It is composed of an impressive number of numbered bottles and assemblage slides for which the catalogue is unfortunately missing (Rögl, 1986, and letter of 28 September 1989).

Family Uvigerinidae Haeckel, 1894

1894 Uvigerinida Haeckel: 185

1927 Uvigerinidae Haeckel; Galloway \& Wissler: 74

1933 Angulogerininae Galloway: 377

1966 Trifarininae Srinivasan: 242

Type genus. Uvigerina d'Orbigny, 1826

Type species. Uvigerina pygmaea d'Orbigny, 1826

Genus Compressigerina Bermúdez, 1949

1949 Compressigerina Bermúdez: 219

Type species. Uvigerina coartata Palmer, 1941, original designation.

Compressigerina coartata (Palmer, 1941)

(Pl.1, figs 5-7)

1941 a Uvigerina compressa Palmer, non Cushman: 182, pl.15, figs 10-11, nom. rej.

1941b Uvigerina coartata Palmer: 304, nom. nov.

1949 Compressigerina coartata (Palmer); Bermúdez: 219

Holotype. 18-64, Paleontological Research Institute, New York.

Type locality. Tejar, San José, Calzada de Marianao, Havana Province, Cuba; Cojimar Formation, Upper Oligocene.

Explanation of Plate 1

Figs 1-4, Reussella spinulosa (Reuss). topotypes from Nußdorff, Vienna Basin; Fig.1,.Habitus, showing the distinct angular outline of the test $(100 \mu \mathrm{m}) ;$ Fig.2, Endview of the test, with the rounded aperture and the low apertural lip surrounding the aperture in a Bulimina-like fashion $(25 \mu \mathrm{m})$; Fig.3, Overview of an opened specimen, showing the regular disposition of the chambers and the succession of the toothplates $(100 \mu \mathrm{m})$; Fig.4, Close-up of a toothplate, demonstrating its bulimine nature $(10 \mu \mathrm{m})$.

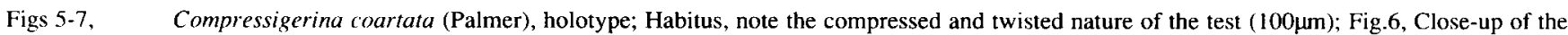
aperture, produced on a Trifarina-like, laterally compressed neck (20um); Fig.7, Internal view of a topotype, showing a foraminal neck and remnants of the toothplate $(25 \mu \mathrm{m})$.

Figs 8.-12, Trimosina milletti Cushman, lectotype; Habitus, note the Reussella-like outline, and the differentiating peripherally produced spine-like extensions of the chambers $(100 \mu \mathrm{m})$; Fig. 9 , Endview, showing the partially broken last chamber with the semi-elliptical upper and slit-like lower aperture $(100 \mu \mathrm{m})$; Fig.10, Paralectotype, habitus $(100 \mu \mathrm{m})$; Fig.11, Apertural view, clearly showing the double aperture $(25 \mu \mathrm{m})$; Fig.12, Kerteh specimen. Internal view with the toothplate sitting over the foramen and attached in different places to the chamber wall $(100 \mu \mathrm{m})$. 


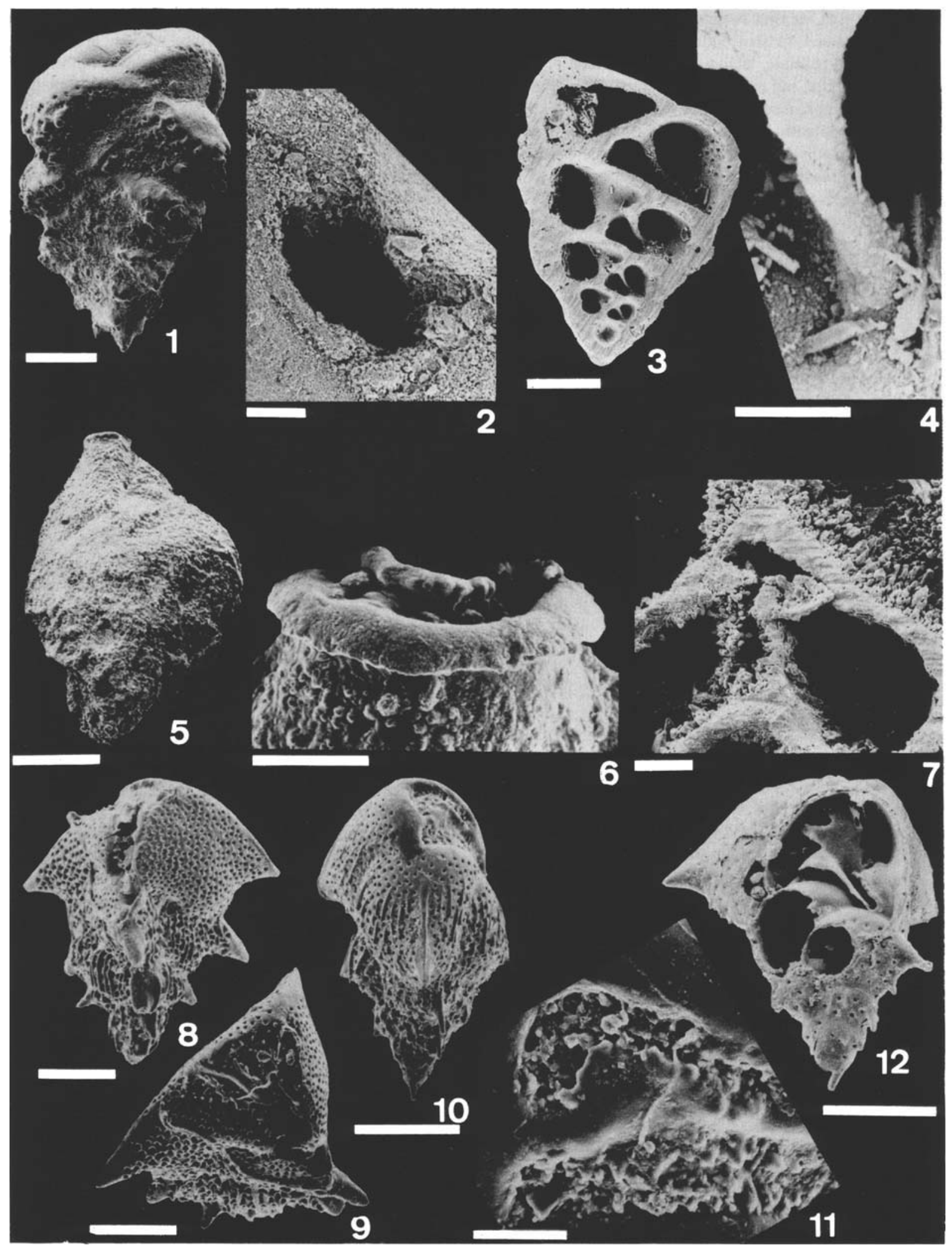


Material examined. The holotype, and topotypes, courtesy P.R. Hoover

Description. Test free, at first rounded in section but quickly reduced to a compressed, twisted outlook, periphery apparently carinate, initial stage triserial, later reduced to twisted biserial; chambers at first rounded and inflated, then laterally compressed; sutures indistinct, depressed; aperture produced on a short, compressed neck, apparently harbouring the cristate top of a lip continuous with the toothplate; wall calcareous, opaque, perforate, earlier parts may be ornamented with fine, low costae.

Remarks. The presence of an aperture produced on a phialine neck with a small everted lip and the angularity of the chambers shows clearly that this genus is allied to Trifarina and Angulogerina. The preservational state of the investigated specimens precludes a complete and detailed description. However, sufficient evidence is available to retain it as a genus in its own right and to prove its alliance to the Uvigerinidae instead of the Reussellidae.

Family Trimosinidae Saidova, 1975

1975 Trimosinidae Saidova: 56

1981 Mimosininae Saidova: 56

Type genus. Trimosina Cushman, 1927

Type species. Mimosina spinulosa var. Millett, 1900, original designation.

Genus Trimosina Cushman, 1927

1927 Trimosina Cushman: 64

Type species. Trimosina milletti Cushman, 1927 (= Mimosina spinulosa var. Millett, 1900). Trimosina milletti Cushman, 1927

(Pl.1, figs 8-12)

1900 Mimosina spinulosa var. Millett: 548, pl.4, fig. 13

1927 Trimosina milletti Cushman: 64, pl.13, fig. 20

Lectotype. 1955:1:1:3543, British Museum (Natural History), London, herein designated.

Type locality. Malay Archipelago, St.13; Recent.

Material examined. 1955:11:1:3543-3642, syntypic series; 1956:6:27:143-148, and 1956:6:27:149-197, Malay Archipelago ex coll. Millett; Andaman Isles, Suez, Coast of Anam, ex coll. Sidebottom; Kerimba Archipelago, also Tibuti, Somaliland, ex coll. Heron-Allen \& Earland; British Museum (Natural History). Specimens from 'Galathea' St.376, 4'30'N 103'28'E, off Kerteh, Trengganu, $-10 \mathrm{~m}$.

Description. Test free, elongate, triangular in section, gradually tapering, chambers arranged in regular triserial series throughout ontogeny, 3 to 4 whorls; chambers subtetrahedral to subspherical, distinctly inflated, drawn-out peripherally into a pointed projection bearing one strong spine; sutures distinct, narrow, depressed, gently arched; aperture double, apertural face not delimited, superior aperture subtriangular, staying below the apex of the chamber, separated from the lower aperture by a fairly narrow thickened band of usually imperforate chamber wall, lower aperture an elongate slit with a denticulate upper edge, parallel to the basal suture, apertures not bordered by an everted lip, toothplate in one part, multiple attachments to the inside of the chamber at the upper aperture; wall calcareous, hyaline, finely and densely perforate, optically distinctly radial, earlier part of the test appears to be ornamented by numerous fine, low ridges running between the pores.

Genus Fijiella Loeblich \& Tappan 1962

1962 Fijiella Loeblich \& Tappan: 109

Type species. Trimosina simplex Cushman, 1929, original designation.

Fijiella simplex (Cushman, 1929)

(PI.2, figs 1-4)

1929 Trimosina simplex Cushman: 158, fig.2

1962 Fijiella simplex (Cushman); Loeblich \& Tappan: 109

Holotype. CC10365, Smithsonian Institution, Washington DC.

Type locality. 40, 50 fms off Fiji; Recent.

Material examined. Holotype and $\mathrm{CC} 10366,12$ paratypes; also

'Galathea' St. $485,8^{\circ} 48^{\prime}$ S $115^{\circ} 16^{\prime} \mathrm{E}$, South of Bali, $-62 \mathrm{~m}$.

Description. Test free, pyramidal to sub-pyramidal, triangular in section, early part regularly increasing in size, later part constant width, 6 whorls, triserial; chambers low tetrahedral, in regular series, flush with the test surface, the outer edge may te slightly spinose; sutures distinct, intercameral ones curved, spiral suture gently undulate; apertural face terminal, apical, triangular and slightly convex, commonly bordered by thickened imperforate rims, ornamented with numerous small upright spines, aperture slit-like, partially covered by a low-lying extensively curved lip, lip divided into two pieces, a larger sigmoidally wrapped denticulate plate and a smaller less denticulate one curved into the hollow left by the larger one; toothplate large, perforated by a few large holes, fuses partly with the foraminal spines, partly with the foraminal lips; wall calcareous, optically distinctly radial, perforate, pores tending to seam the edges of the individual chambers, often slightly produced on low mounds.

Remarks. Although superficially similar to Reussella, the peculiar apertural face and especially the toothplate show it to be

Explanation of Plate 2

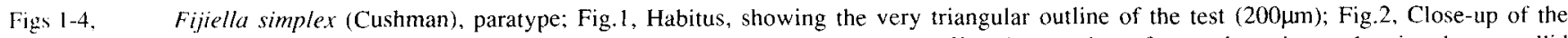
apertural face, with the highly convoluted, double lip $(50 \mu \mathrm{m})$; Fig.3, South off Bali. Overview of opened specimen, showing the reussellid organisation of the test $(100 \mu \mathrm{m})$; Fig.4, Close-up of two successive toothplates, with the peculiar attachment mode visible in the lower part $(50 \mu \mathrm{m})$.

Figs 5-11, Mimosina hystrix Millett, lectotype; Fig.5, Habitus, (Microspheric) showing the mixed seriality and the characteristic outwardly projecting

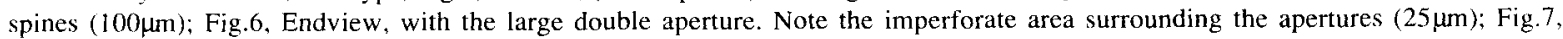

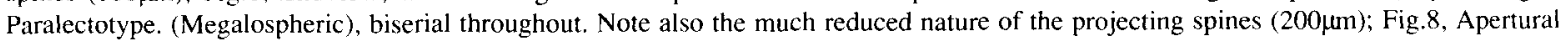

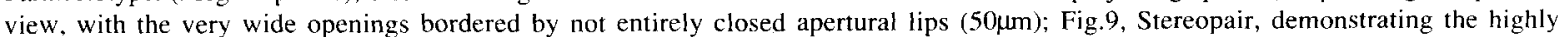
complicated nature of the toothplate and its relation to the aperture and foramen (100um); Fig.10, Close-up of a juvenile chamber. Note the

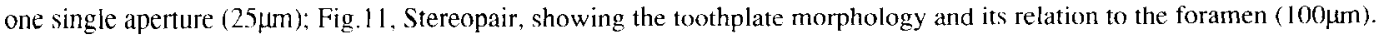




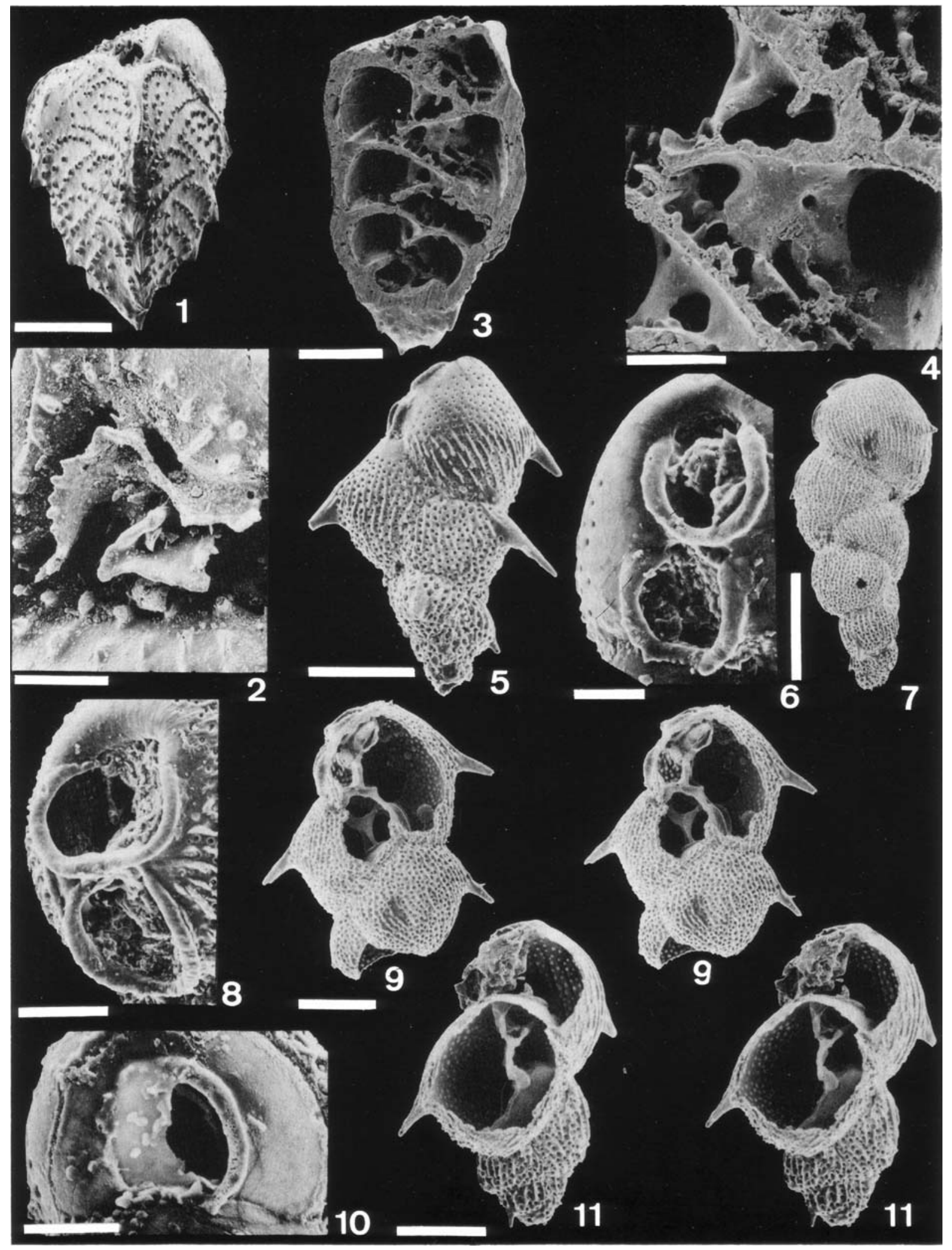


a distinct genus. The apertural face is covered with spines and tubercles which may deceive one into believing that a supplementary cribrate aperture is present. If extra openings are at all present then it is due to subsequent damage or perhaps reproduction.

\section{Mimosina Millett: 547}

Genus Mimosina Millett, 1900

Type species. Mimosina histrix Millett, 1900, subsequent designation by Cushman, 1927.

Mimosina histrix Millett, 1900

(Pl.2, figs 5-11)

1900 Mimosina hystrix Millett: 549, pl.4, figs 14, 15

1927 Mimosina hystrix Millett; Cushman: 64

Lectotype. ZF4903, British Museum (Natural History), London, herein designated.

Type locality. Malay Archipelago, St. 10; Recent.

Material examined. 1955:11:1:3382-3394, and slide Malay St. $10 \& 27$ ex coll. Millett, syntypic series; British Museum (Natural History).

Description. Test free, elongate, tapering, slowly but regularly increasing in width, triserial in juvenile stage, later chambers arranged in biserial series; chambers very inflated, spherical, with an outwards projecting spine arising in the middle of the chamber; sutures distinct, depressed, gently arcuate; aperture double, no delineated apertural face, aperture turned towards the coiling axis, upper aperture almost terminal, rounded, bordered by a thickened low lip, separated from the lower aperture by a small ridge of perforated chamber wall, lower aperture more ovate, also bordered by a low, thickened lip; toothplate starts from the upper end of the topmost aperture and curves towards the toothplate bending downwards from the ridge between the two apertures, the lower toothplate continues towards the foramina and fuses with the foramen sitting over the top foraminal opening; wall calcareous, hyaline, distinctly and densely perforate, the wall may be ornamented with thin, short ridges running parallel to each other.

Remarks. The description covers the majority of specimens, apparently belonging to the microspheric generation. A few specimens were found which appear to be megalospheric. These differ from the microspheric ones in being biserial throughout, having more spherical chambers with much reduced projecting spines, and in having more prominent and larger apertural openings. It seems that the aperture becomes double only later in ontogeny as observation of some of the earliest chambers shows only a single aperture.
Family Turrilinidae Cushman, 1927

1927 Turrilininae Cushman: 65

1961 Turrilinidae Cushman: Loeblich \& Tappan: 300

1982 Praebuliminidae Loeblich \& Tappan: 33, not available

1984 Praebuliminidae Loeblich \& Tappan: 43

Type genus. Turrilina Andreae, 1884

Type species. Turrilina alsatica Andreae, 1884

Genus Pyramidina Brotzen, 1948

1948 Pyramidina Brotzen: 62

Type species. Bulimina curvisuturata Brotzen, 1940, original designation.

$$
\text { Pyramidina curvisuturata (Brotzen, 1940) }
$$

(Pl.3, figs 1-3)

1940 Bulimina curvisuturata Brotzen: 29, fig.4

1948 Pyramidina curvisuturata (Brotzen); Brotzen: 62

Holotype. Riksmuseet, Stockholm.

Type locality. Klagsham, South Sweden; Upper Danian.

Material examined. Topotypes, courtesy H.J. Hansen.

Description. Test free, elongate, broadly ellipsoid in outline, periphery slightly lobulate, bluntly triangular in endview, triserial, 2 to 3 whorls; chambers moderately inflated, regularly increasing in size, somewhat angular but broadly rounded; sutures indistinct, slightly depressed, gently curved; aperture subterminal, elliptical, bordered by a low, thickened lip, clearly separated from the basal suture; a straight, narrow toothplate runs from aperture towards the foramen where it is apparently attached adjacent to the top of the foramen, running over a short distance as the plate narrows during its descent; wall calcareous, perforate, opaque.

Remarks. All available specimens have been subject to various degrees of diagenesis, thus hindering critical observations.

Superfamily Pavoninacea Eimer \& Fickert, 1899

Nom. transl. ex fam. Pavoninidae Eimer \& Fickert, 1899

1962 Loxostomidae Loeblich \& Tappan: 110

1981 Loxostomidea Loeblich \& Tappan: Saidova: 60

1987 Loxostomatacea Loeblich \& Tappan; Loeblich \& Tappan: 500

Description. Test free, multilocular, chambers in high trochospiral coils, pluriserial to rectilinar, no internal structures between aperture and foramen, wall calcareous, bilamellar, perforate.

Member taxa: Pavoninidae, Buliminellidae, Buliminoididae and Loxostomatidae.

Family Pavoninidae Eimer \& Fickert, 1899

1899 Pavoninidae Eimer \& Fickert: 606

1927 Pavonininae Eimer \& Fickert; Cushman: 59

Type genus. Pavonina d'Orbigny, 1826

\section{Explanation of Plate 3}

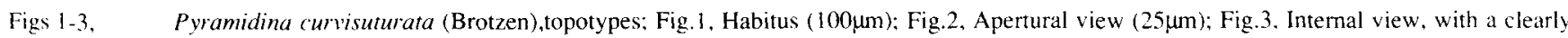
defined but diagenetisised toothplate $(25 \mu \mathrm{m})$.

Figs. 4.9. Pavonina flabelliformis d Orbigny, topotype: Habitus (200 $\mu m)$; Fig.5. Raine Island. Habitus of a juvenile specimen. Note especially the

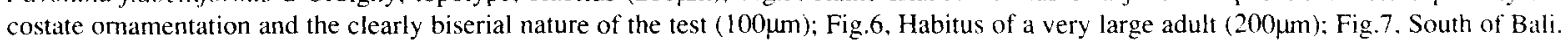
An opened specimen, showing the simple nature of the test $(200 \mu \mathrm{m})$ : Fig.8. Close-up of the upper edge of the test. Note the many tubercles and the apparent absence of apertural openings $(25 \mu \mathrm{m})$; Fig.9. Close-up of the wall, showing the tubulopore-like openings.

Figs 10-12. Bifarinella ryukyuensis Cushman \& Hanzawa. Macassar Strait; Fig.10, Habitus. Note the very prominent tubulopore-like openings and the initial pluriseriality $(200 \mu \mathrm{m})$; Fig.11. Endview. The aperture appears to consist in a large slit. subdivided by smaller partitions (200)um): Fig.12, South off Bali. Opened specimen. showing the simple nature of the internal organisation ( $200 \mu \mathrm{m})$. 


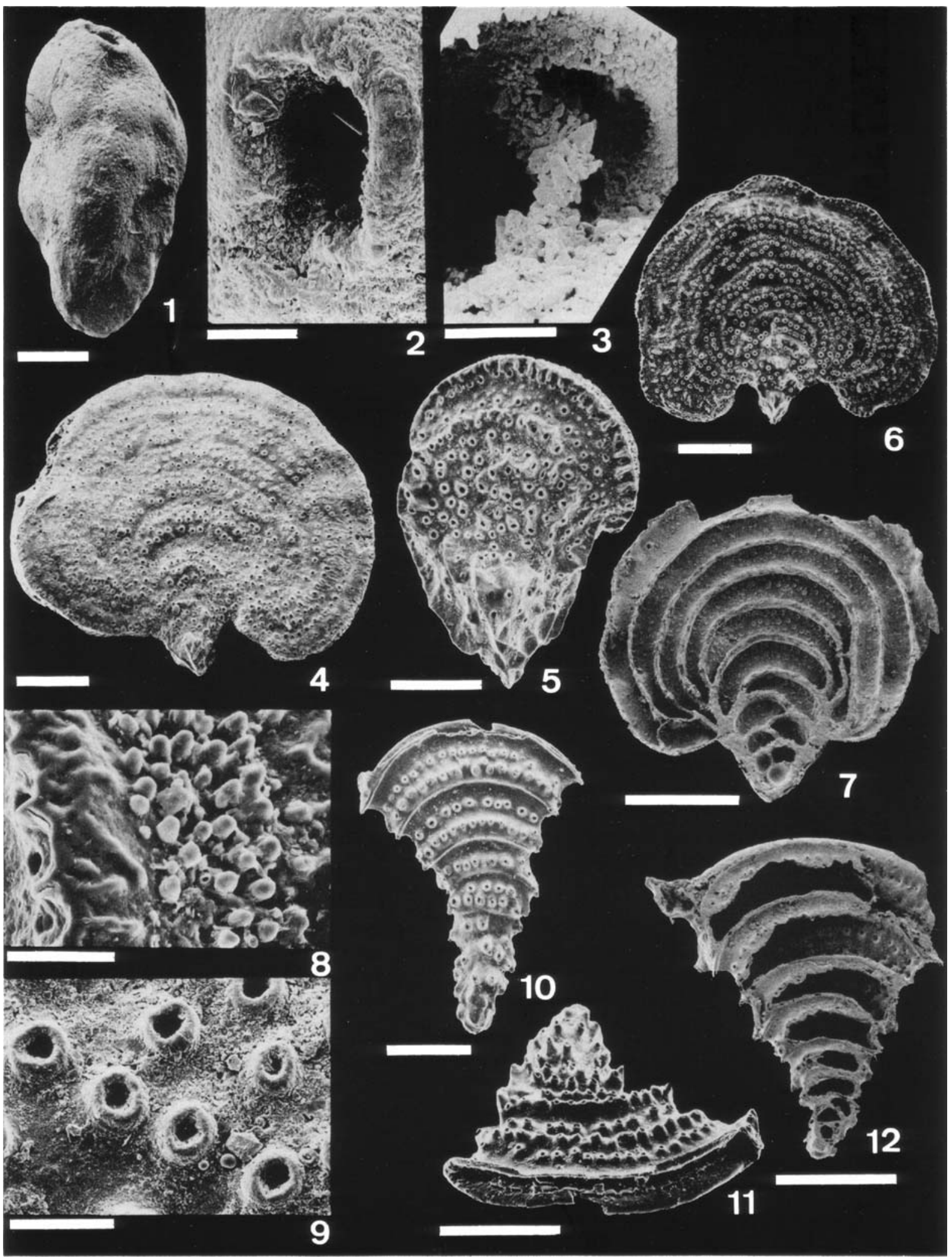


Genus Paromina d Otbigny, 1826

1826 Pavinina d Orbigny: 260

1951 lalroparonina Hother: 35. objective synonym

Type species. Pavonina flabolliformis d'Orbigny, 1826, type by monotypy.

Paromina flabelliformis d’Orbigny, 1826

(Pl.3, figs.4-9)

1826 Paronina flabelliformis d'Orbigny: 260, pl.10, figs 10-12

1846 Pavonima flabelliformis d'Orbigny: 72 , pl.21, figs 9-10

Holotype. FO100, Muséum National d'Histoire Naturelle, Paris,

holotype by monotypy.

Type locality. Madagascar; Recent.

Material examined. The holotype, and topotypes from d'Orbigny's original sample, Muséum National d'Histoire Naturelle, Paris. 1955:10:21:341-347, Ibo, and 1955:11:3:788, Kerimba Archipelago, ex coll. Heron-Allen \& Earland; P50121, Topogi River, Topogi Formation, Borneo, Pliocene, ex coll. Whittaker; 1959:5:5:900-906, Shore Sands of Madagascar; ZF 2070, Honolulu, 'Challenger' Station 260A; ZF 2072, Off Calpentyn, Ceylon; 1956:1:7:241-243 and 244-250, Samoa; 1956:1:6:578-595, Taviumi, Fiji; 1955:5:5:1448, Seychelles, ex coll. Brady; off Bermuda, ex coll. Pearcy; Gulf of Manara, Ceylon; Andaman Isles, ex coll. Sidebottom; South of Tenerife, 'Challenger' Station 1; Torres Strait; Java, ex coll. Millett; Kerimba Archipelago, balsam embedded, ex coll. Heron-Allen \& Earland; Ibo, East Africa; Raine Island, 'Challenger' Station 185; Barbados; Vavau Anchorage, Fiji; Mauritius, outer Harbour, all ex coll. Heron-Allen \& Earland; British Museum (Natural History).

Specimens from 'Galathea' St. $485,8^{\circ} 48^{\prime} \mathrm{S} 115^{\circ} 16^{\prime} \mathrm{E}$, South of Bali, - 62m.

Description. Test free, fan-shaped, compressed, initial stage biscrial, after about 8 chambers apparently becoming uniserial, due to the embracing of the successive chambers; chambers initially rounded, then laterally compressed and quickly becoming semi-lunar and more and more embracing; sutures distinct, arched; primary aperture appears to be absent but larger pores occur between the tubercles on the side rim of the chamber, chamber interior simple; wall calcareous, hyaline, optically distinctly radial, a septal flap is present, perforate, pores very large, on low raised mounds, arranged in a single row bordering the chamber edges, sometimes with a supplementary row.

Remarks. The presence of a septal flap in this species adds weight to the calls for relinquishing this characteristic for taxonomic purposes above the species level. The absence of a well defined primary aperture makes this an unusual taxon. The ridges present in some specimens indicate that the earliest part may be twisted biserial, but it is never truly triserial.

Genus Finlayina Hayward \& Morgans, 1981

1981 Finlayina Hayward \& Morgans: 439

Type species. Finlayina hornibrooki Hayward \& Morgans, 1981, original designation.

Finlayina hornibrooki Hayward \& Morgans, 1981

(Pl.4, figs 1-3)

1981 Finlayina hornibrooki Hayward \& Morgans: 439, figs 1-11

Holotype. TF 1596/1, New Zealand Geological Survey.

Type locality. J41/8609, Taylor's Quarry, Oamaru, N. Otago, New Zealand; McDonald Limestone, Lower Oligocene.

Material examined. TF 1596/10, 11 paratypes, courtesy B. Hayward.

Description. Test free, irregularly fan-shaped, laterally very compressed, first 14 chambers biserial, then uniserial, producing a central zigzag pattern in the lower part of the test; chambers numerous, semi-lunar, very much drawn-out and very low, almost lint-like, regularly increasing in length, except when changing from biserial to uniserial coiling, not embracing; sutures indistinct, flush with the surface; aperture at the outer upper edge of the chamber, composed of multiple irregular openings, internal structures absent; wall calcareous, perforate, opaque.

Remarks. Differs from Pavonina in lacking the characteristic 'tubulopores' and the low tubercles sown all over the outer chamber edge, in being distinctly biserial for some 14 chambers, and in lacking the discrete costulation in the earlier part of the test. All available specimens show the effects of heavy diagenesis, thus making critical observations impossible.

This species appears to be related to Quasibolivinella taylori Quilty, 1981. Although the latter is reported to be biserial throughout, it shows the same disposition of the earliest chambers, and both the surface and outline are remarkably similar.

Genus Bifarinella Cushman \& Hanzawa, 1936

1936 Bifarinella Cushman \& Hanzawa: 45

Type species. Bifarinella ryukyuensis Cushman \& Hanzawa, 1936, original designation.

Bifarinella ryukyuensis Cushman \& Hanzawa, 1936 (Pl.3, figs 10-12)

1936 Bifarinella ryukyuensis Cushman \& Hanzawa: 46, pl.8, figs 7,8

Explanation of Plate 4

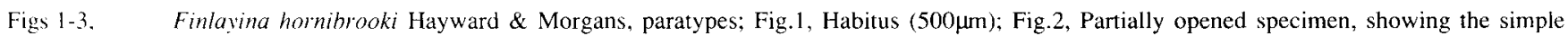
nature of its organisation $(250 \mu \mathrm{m})$; Fig.3, Endview of the test. Note the apparent absence of apertural openings $(100 \mu \mathrm{m})$.

Figs 4-6, Chrysalidinclla dimorpha (Brady), holotype; Fig.4, Habitus. Note the slightly ornamented nature of the initial part of the test (150um); Fig.5, Endview, showing the larger openings making up the aperture $(50 \mu \mathrm{m})$; Fig.6, Kerteh. Opened specimen, demonstrating the simple nature of the internal organisation $(100 \mu \mathrm{m})$.

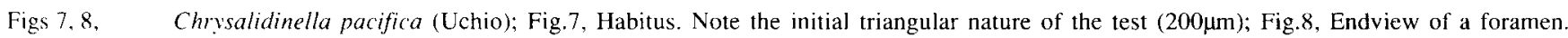

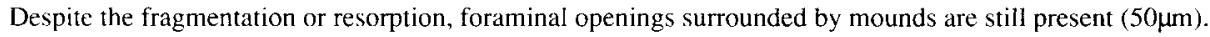

Figs 9-12, Cifellia costata (Heron-Allen \& Earland), lectotype; Fig.9, Habitus. The initial coiling appears to be triserial. Note the relation of the

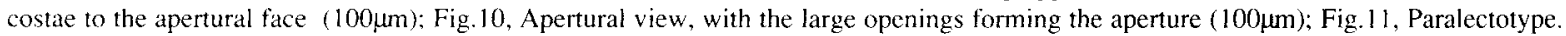

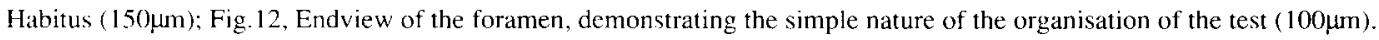



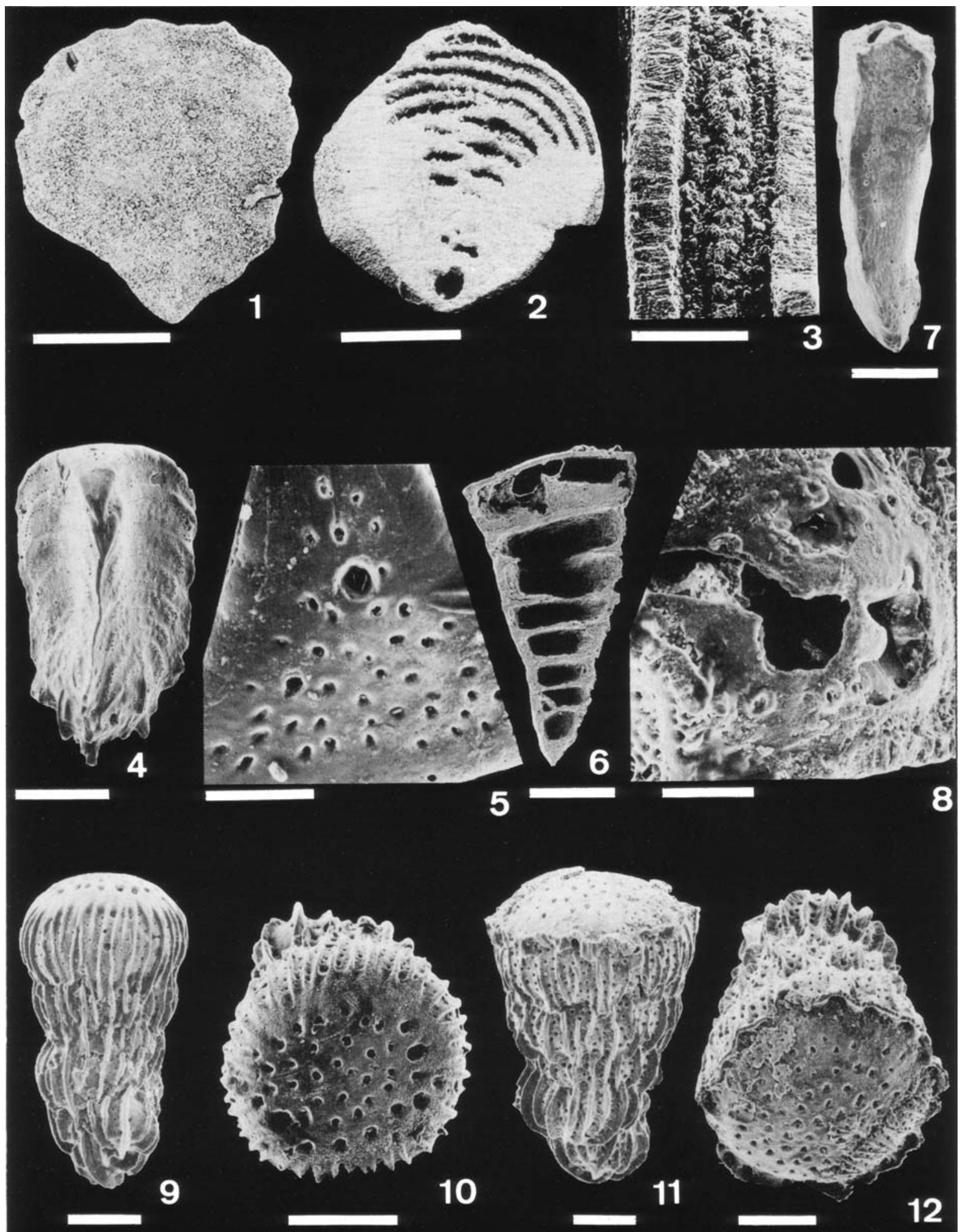
1964 Pavonina ryukyuensis (Cushman \& Hanzawa); Loeblich \& Tappan: 563, fig.444-4

Holotype. CC 23141, Smithsonian Institution, Washington DC. Type locality. $500 \mathrm{~m}$ North of Kamikatetsu, Kikar-Jima, Ryukyu, Japan; Ryukyu Limestone, Pleistocene.

Material examined. Holotype and CC 23142, 2 paratypes; also Macassar Strait, - $45 \mathrm{fms}$; Timor Sea, - $30 \mathrm{fms}$, ex coll. HeronAllen \& Earland; Cebu, ex coll. Sidebottom; all labelled “'Bifarina mackinnonii'; British Museum (Natural History).

'Galathea' St. $490,5^{\circ} 25^{\prime}$ 'S $17^{\circ} 03^{\prime} \mathrm{E}$, Bali Sea, - 570m.

Description. Test free, triangular flaring, compressed, initially biserial, but after about 4 to 5 chambers becoming rectilinear; chambers at first semi-lunar, but quickly becoming crescentic, regularly increasing in size; sutures distinct, arcuate; aperture not recognised, interior of the chambers simple; wall calcareous, optically distinctly radial, perforate, pores large, on top of low mounds, concentrated along the sutural edges, but also on the free chamber wall.

Remarks. The genus differs from Pavonina by lacking embracing chambers and having a much reduced biserial part. The pores are much more prominent close to the sutural junctions and later chambers are crescentic, rather than reniform as in Pavonina.

Genus Chrysalidinella Schubert, 1908

1908 Chrysalidinella Schubert: 242

1952 Chrysalidinoides Uchio: 154

Type species. Chrysalidina dimorpha Brady, 1881, original designation.

\section{Chrysalidinella dimorpha (Brady, 1881)}

$$
\text { (PI.4, figs 4-6) }
$$

1881 Chrysalidina dimorpha Brady: 54

1884 Chrysalidina dimorpha Brady; Brady: 388, pl.46, figs 21,22

1908 Chrysalidinella dimorpha (Brady); Schubert: 243

1951 Chrysalidinella dimorpha (Brady); Hofker: 175, figs 110112

Holotype. ZF 1273, British Museum (Natural History), London. Holotype by monotypy.

Type locality. Hong Kong Harbour, - $7 \mathrm{fms}$, 'Challenger' Station 205A; Recent.

Material examined. The holotype; also 1955:5:5:55-59, Tamatavé, Madagascar; 1955:11:1:745-748, Malay Archipelago Stations 14 \& 22, ex coll. Millett; ZF 340, Gulf of Aden, - 37m, 'John Murray' Station 27; P50124 Topogi River, Topogi Formation, N. Borneo, Pliocene, ex coll. Whittaker; British Museum (Natural History). 'Galathea' St. 379, 4³8'N 10339'E, off Kerteh, Trengganu, $-40 \mathrm{~m}$.

Description. Test free, triangular, earlier part may be pluriserial, most of the test rectilinear; chambers triangular, low, well delineated by distinct imperforate band, the outer edge may be reinforced by a slightly carinate edge; sutures distinct, gently curved; true aperture absent, but the apex of each chamber is pierced by an irregular group of larger rounded openings, no internal structures; wall calcareous, hyaline, heavily perforate, coarse pores in regular rows, somewhat smaller than the terminal pores.

Remarks. It seems that dimorphism is present in this species, to the extent that microspheric individuals have a pluriserial initial test, while megalospheric ones are rectilinear throughout.

$$
\text { Chrysalidinella pacifica (Uchio, 1952) }
$$

$$
\text { (Pl.4, figs 7-8) }
$$

1952 Chrysalidinoides pacificus Uchio: 154 , pl.7, fig.6

1964 Chrysalidinella pacifica (Uchio); Loeblich \& Tappan: 563 , fig. $444 / 10$

Holotype. CF 3036, Geological Institute, University of Tokyo.

Type locality. Yaene Beach, Ogago-mura, Hachijo Island, Japan; Recent.

Material examined. Specimen from 'Challenger' Type Slide TS C16, square 3, labelled Chrysalidina dimorpha by Sidebottom, British Museum (Natural History), London.

Description. Test free, elongate, at first triangular in section, but quickly becoming quadrangular, triangular part multiserial, then reduced to uniserial; chambers flush with the surface, tetrahedral to sub-cubic, not clearly delimited; primary aperture not observed, foramen pierced by relatively large rounded openings bordered by a low rim, scattered over the septal face; wall calcareous, distinctly perforate.

Remarks. Chrysalidinoides was synonymised by Loeblich \& Tappan (1964) with Chrysalidinella on the grounds that quadrangularity is known to be adventituous in many dominantly triangular forms. Specimens of the 'Challenger' material seen by me reinforce this conclusion, since some of them are quadrangular later in ontogeny. The species pacifica is maintained as it can be differentiated from $C$. dimorpha by the pores being barely produced and the openings on the apertural face being bordered by low rims (plate 4 , fig.9).

$$
\text { Genus Cifellia Gibson, } 1989
$$

\section{Cifellia Gibson: 141}

Type species. Chrysalidina costata Heron-Allen \& Earland, 1924, original designation.

$$
\begin{gathered}
\text { Cifellia costata (Heron-Allen \& Earland, 1924) } \\
\text { (P1.4, figs 9-12) }
\end{gathered}
$$

1924 Chrysalidina costata Heron-Allen \& Earland: 139, pl.8, figs $12-14$

1937a Chrysalidinella costata (Heron-Allen \& Earland); Cushman: 55

Explanation of Plate 5.

Figs 1-9, Orthocerina quadrilatera d'Orbigny,topotypes; Figs 1-3, Habitus. Note the irregularity in the later stages of ontogeny (1:200 $\mu$ m, 3, 4:

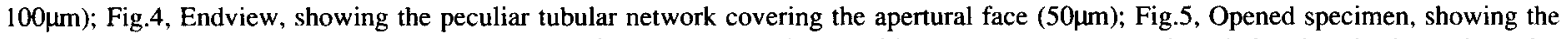
organisation of the test $(200 \mu \mathrm{m})$; Fig.6, Endview of a younger specimen, with a more sparse network and showing the large, irregular apertural openings $(50 \mu \mathrm{m})$; Figs $7-9$, Close-ups of the tubular networks. Note especially the absence of contact between successive networks and the large, irregular holes in the test wall underlying the networks $(50 \mu \mathrm{m})$.

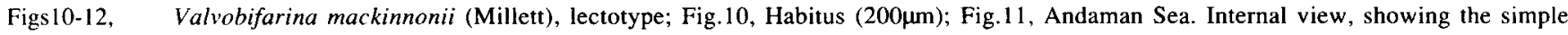
organisation of the test $(100 \mu \mathrm{m})$; Fig.12, Close-up of an earlier foramen, showing the lip protruding in the lumen and demonstrating the absence of a toothplate $(25 \mu \mathrm{m})$. 


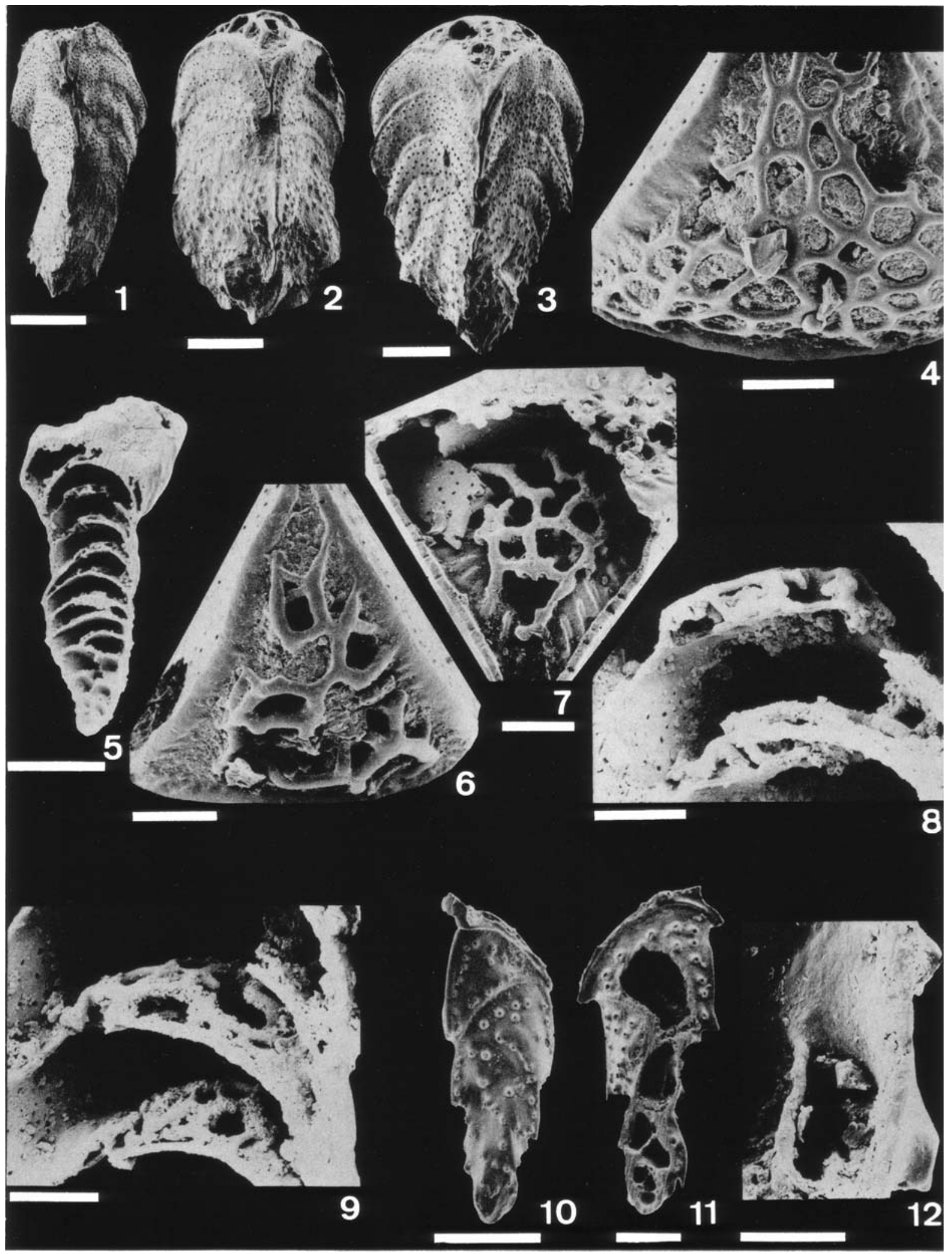


1989 Cifellia costata (Heron-Allen \& Earland); Gibson: 141, pl.7, figs $1-8$

Lectotype. P 35532, British Museum (Natural History), London, herein designated.

Type locality. Filter Quarry, Moorabool River, Victoria, Australia; Polyzoal Limestone, Batesfordian, Miocene.

Material examined. The syntypic series P 35530, P 35531 and P 35532; British Museum (Natural History), London.

Description. Test free, elongate, rounded in section, regularly increasing in diameter, periphery lobulate, juvenile triserial, quickly reduced to a rectilinear series; chambers subspherical, very inflated, up to 6 uniserial chambers; sutures indistinct, depressed, annular; apertural face apical, rounded, somewhat flattened, bordered by an imperforate peripheral band, pierced by a large number of circular openings; no internal structures; wall calcareous, finely and densely perforate, ornamented by numerous thin costae, undercut at the sutural joints.

Genus Orthocerina d'Orbigny, 1839

1826 Nodosaria (Orthocérine) d'Orbigny: 255, unavailable 1839 Orthocerina d'Orbigny: 17

Type species. Orthocerina quadrilatera d'Orbigny, 1839 by monotypy

non 1933 Orthocerina clavulus d'Orbigny; Galloway: 217, pl.19, fig. 14, nom. nov. pro Spirolinites cylindricacea var B Lamarck, 1804 , unavailable name

non 1863 Orthocerina murchisoni (Reuss); Parker \& Jones: 433

Orthocerina quadrilatera d'Orbigny, 1839

(Pl.5, figs 1-9)

1839 Orthocerina quadrilatera d'Orbigny: 18, pl.1, figs 11-12 1930 Orthocerina quadrilatera d'Orbigny; Heron-Allen \& Earland: 172

1964 Orthocerina quadrilatera d'Orbigny; Loeblich \& Tappan: 785, deemed unrecognisable

1977 Orthocerina quadrilatera d'Orbigny; Le Calvez: 60, deemed unrecognisable

Holotype. FO 271, holotype by monotypy, Muséum National d'Histoire Naturelle, Paris.

Type locality. Cuba; Recent.

Material examined. The holotype, and topotypes from Cuba and Jamaica recovered from the original d'Orbigny samples, Muséum National d'Histoire Naturelle, Paris. Specimens from the Dry Tortugas, courtesy P. Hallock-Muller.

Description. Test free, elongate, angular, width fairly uniform, later in ontogeny somewhat irregular outline, usually triangular in section, quadrangularity adventitious, early part triserial, then uniserial; chambers subtetrahedral, angular, lower than wide, at first flush with the test, later in ontogeny overlapping and irregularly arranged over the test; sutures distinct, flush with the surface, may be slightly raised, distinctly curved upwardly; apertural face apical, triangular, aperture multiple, composed of fairly large irregular openings, apertural face covered by a lowlying network of massive cylindroid structures apparently delimiting the apertural openings, no internal structures; wall calcareous, hyaline, distinctly perforate, pores usually arranged in rows parallel to the sutures, raised on low mounds, giving a 'tubulopore'-like impression.

Remarks. The tubular network on top of the apertural face very often has foreign material trapped in the gaps, obscuring the apertures. This may to some extent explain why the original description by d'Orbigny mentions only a single opening. Le Calvez (1977) states that the only available specimen, contrary to d'Orbigny's description, actually possesses a multiple aperture: "...alors qu'il s'agit de pores disséminés sur toute la face orale". Due to curatorial policy, it is impossible to investigate the holotype of Orthocerina in full detail. However, specimens recovered from d'Orbigny's original samples seem to fit the original description, bearing in mind the different degrees of resolving power of our respective instruments. I feel confident that the true nature of Orthocerina is here adequately presented.

The type specimen of Orthocerina is quadrangular in section, but all specimens recovered from the Cuba and Jamaica samples originally used by d'Orbigny are triangular. I maintain that triangular and quadrangular specimens are conspecific, as is indeed the case for Chrysalidinella (q.v.).

Genus Valvobifarina Hofker, 1951

1951 Valvobifarina Hofker: 39

Type species. Bifarina mackinnonii Millett, 1900, original designation.

Valvobifarina mackinnonii (Millett, 1900)

(Pl.5, figs 10-12)

1900 Bifarina mackinnonii Millett: 281 , pl.2, fig. 15

1937b Bifarina mackinnoni Millett; Cushman: 200, pl.23, fig.6 only, err. cit.

1951 Valvobifarina mackinnoni (Millett); Hofker, 1951: 40, err. cit.

Lectotype. 1955:11:1:121, British Museum (Natural History), London, herein designated.

Type locality. Macassar Strait, $-45 \mathrm{fms}$, Malay Archipelago; Recent.

Material examined. Lectotype and 1955:11:1:121, paralectotypes; 1962.9.7.1-5, from Macassar Strait, ex Millett coll.; Macassar Strait, ex coll. Sidebottom; Sulu, ex coll. Sidebottom; Timor Sea, -30fms, ex coll. Heron-Allen \& Earland; Java, ex coll. Millett; specimens from the Kerimba Archipelago, ex Heron-Allen \& Earland coll.; British Museum (Natural History). Specimens from 'Galathea' Station 379, 4'38'N $103^{\circ} 39^{\prime} \mathrm{E},-40 \mathrm{~m}$, off Kerteh, Trengganu; 'Galathea' Station 404 , $5^{\circ} 09^{\prime} \mathrm{N} 106^{\circ} 47^{\prime} \mathrm{E},-63 \mathrm{~m}$, South China Sea; 'Galathea' Station 490, $5^{\circ} 25^{\prime} \mathrm{S} 117^{\circ} 03^{\prime} \mathrm{E},-570 \mathrm{~m}$, Bali Sea. Geological Museum, Copenhagen.

Description. Test free, elongate, initially triserial, but later reduced to biserial; chambers at first rounded to tetrahedral, but quickly becoming angular, cuneate and laterally compressed with a spine at the lowermost point, individual chambers well marked; sutures distinct; aperture an elongate slit at the apex, slightly everted, interior of the chambers simple; wall calcareous, optically distinctly radiate, perforate, pores coarse, at the top of low mounds, concentrated at the edges of the cuneate chambers.

Remarks. The specimens of $V$. mackinnonii figured by Millett, supposedly from the Malay Archipelago, should be considered lost. Courtesy of Mr Hodgkinson (BMNH), the following details relevant to the Millett collection have come to light. The Millett collection was salvaged through effective action taken by HeronAllen after Millett's death. Apparently, Heron-Allen found the collection in Millett's house in a very derelict state, with many of the slides open, quite damp, attacked by mould and buried under great piles of dust and rubbish. Heron-Allen tried to rescue as 
much as possible, but obviously losses were unavoidable. This also explains the precarious and fragile state of many of the specimens in the Millett collection.

\section{Genera attributed to the Reussellidae \\ Genus Acostina Bermúdez, 1949}

1949 Acostina Bermúdez: 152

Type species. Chrysalogonium pyramidale Acosta, 1940, original designation.

Acostina pyramidale (Acosta, 1940)

1940 Chrysalogonium pyramidale Acosta: 4, pl. I, figs 4-5

1949 Acostina pyramidale (Acosta); Bermúdez: 152

1964 Acostina pyramidale (Acosta); Loeblich \& Tappan: 563, fig. 444-6

Holotype. Apparently lost, Smithsonian Institution, Washington DC (Buzas, written comm.). Cotypes should be present in the Museo Poey, Havana University, Cuba.

Type locality. North Coast of Cuba, 20'34'N 74'24'W, -1300m, 'Atlantis' St. 2971.

Remarks. No specimens have come to hand for investigation. However, based on the drawings provided by Acosta, I wish to make the following suggestions. The triangular shape of the test and the form of the chambers seems to indicate some affinity to Tristix MacFadyen, 1941 or some other Nodosariid taxon. Until specimens become available for further investigation, I propose to remove Acostina from the reussellid taxa and to consider it as incertae sedis.

\section{DISCUSSION}

The general habitus of the species studied falls in the category of the high trochospiral forms. The test is elongated along the coiling axis, and the seriality is reduced. Most of the species investigated exhibit a mixed seriality: the juvenile test is often tri- or biserial, but soon becomes reduced (Bifarinella, Chrysalidinella, Cifellia, Finlayina, Mimosina, Orthocerina, and Valvobifarina). It seems that this mixed seriality is linked in at least some of the genera to reproductive dimorphism. There are indications that a correlation exists between the size of the proloculus and the occurrence of a pluriserial juvenile part; i.e. the microspheric generation seems to start a test pluriserially, while the megalospheric generation is rectilinear from the very beginning (e.g. Chrysalidinella, Cifellia, maybe also Orthocerina). Others remain triserial throughout their ontogeny (Fijiella, Mimosina, Pyramidina and Reussella), irrespective of the generation.

The shape of the chamber is quite varied. Contrary to the other representatives of the Buliminacea, characterised by spherical or at least broadly rounded chambers, many of the 'reussellid' genera have tetragonal chambers with true triangular faces, sharp corners and edges. Others possess curiously modified chamber forms such as cuneate (Valvobifarina), ribbon-shaped (Bifarinella), or reniform chambers (Pavonina, Finlayina).

The pores in the wall of tests also show some interesting variety. In many cases the pores are arranged in neat rows paralleling the sutures of the chambers. In some taxa (e.g. Bifarinella, Valvobifarina), the pores are produced on small mounds, vaguely reminiscent of the tubulopores in Tubulogenerina (see Gibson, 1987).

The habitus of the test in these genera has been used extensively to classify them more or less together on the family level. The apparent recurrency of early 'reussellid' coiling together with historic tradition are the main reasons behind this taxonomic arrangement. The use of internal anatomical features has never before been attempted for the genera here under study. As was the case for some of the buliminid genera, the inclusion of these characteristics in the analysis is a great help in clarifying the true relations between the genera (Revets, 1989).

The apertural complex in the taxa investigated is highly varied or even unknown. Upon opening the specimens, a fundamental divide can be made immediately, depending on the presence or absence of a toothplate. The apertural complex is intimately related to the toothplate, so that a fairly large set of characters are available for systematic purposes. The apertural face ranges from a typical bulimine one (Reussella) to a simple plane pierced by larger, irregularly arranged openings (Chrysalidinella). Peculiar modifications do occur such as the tubular net in Orthocerina, or the heavily sculptured lips in Fijiella, and even the presence of more than one primary opening as in Mimosina and Trimosina.

As is the case for Bulimina-like taxa, there is a clear relation between the apertural face and the presence (and indeed morphology) of the toothplate. All taxa with an un-bulimine aperture lack any form of toothplate (Bifarinella, Chrysalidinella. Cifellia, Finlayina, Orthocerina, Pavonina, Valvohifarina). The remaining genera possess a toothplate with varying degrees of complexity. The simplest toothplate is encountered in Reussella. in which a typically bulimine toothplate connects aperture with foramen, its relation to the apertural lip included. Complexity increases with Fijiella (with rather disturbing reminiscences to the apertural complex in Sagrina pulchella, type species of Sagrina d'Orbigny, 1839 [study in progress]), and finally a very convoluted morphology, quite different from the bulimine toothplates, is found in Trimosina and especially in Mimosina.

From early on in the endeavours towards classification. Reussella has been more or less allied to Bulimina. The perceived similarities between representatives of these two genera were based exclusively on the gross outer morphology. Before the work by Hofker (1951), all students seem to have been unaware of the presence of an internal toothplate in Reussella (e.g. Galloway. 1933, p.357-358; Cushman, 1927, until the last re-edition in 1948). Surprisingly, Galloway (1933) uses implicitly the presence of an internal plate in Bulimina to separate Reussella from Bulimina in the subfamily Turrilininae.

Hofker (1951) depicted two new species of Reussella. besides giving a drawing of the toothplate of what he identified as $R$. spinulosa. From the text, it appears that he studied Recent specimens only. The toothplate figured for Reussella spinulosa seems to be that of specimens from the seas around Borneo and Celebes rather than from Miocene Reussella specimens of the Vienna Basin: apparently he identified some of the Recent forms as $R$. spinulosa (Hofker, 1951, p.143).

Loeblich \& Tappan (1964, also 1987) reproduced Hofker's drawing of the toothplate of Reussella spinulosa sensu Hofker. and figured two specimens from the Miocene of the Vienna area. One of the specimens drawn agrees very well with the figures provided by Reuss, but the other specimen fits Reussella pulchra Cushman, 1945, also from the Vienna Basin. The toothplate is similar to the one in Bulimina marginata (Revets, 1989, plates 1 
\& 2). This stands in sharp contrast to the toothplate depicted by Hofker (1951), and later reproduced in all major classifications. Since Hofker only used Recent representatives from the Pacific Province, it is almost certain that the specimens identified by Hofker as $R$. spinulosa belong in fact to quite a different species, and maybe even to Fijiella. Furthermore, the morphology of the apertural face and the coiling mode are the same as in Bulimina. The chief difference between the two genera is the form of the chambers, which is tetrahedral in Reussella and rounded in Bulimina, and the orientation of the aperture, lying in a Turrilinalike fashion in Reussella rather than running up the apertural face.

Since the organisational principle of Reussella is shown to be matching that of Bulimina, Reussella is here reclassified in the Buliminidae. A difference in chamber form is useful to characterise genera, but does not constitute in itself a sufficient criterion to separate families. Recent specimens of Reussella only confirm this observation: although many of the species seen have a much larger aperture than $R$. spinulosa, it is still clearly of the bulimine type, albeit oriented more in a Turrilina-like fashion. However, the strict triseriality and the low, barely ornamented apertural lip shows the affinity to be bulimine, rather than turriline.

The genus Fijiella, originally separated from Trimosina, is very different from Reussella, anatomically speaking. The apertural face is much larger and flatter, ornamented by upwards projecting short spines, and the aperture itself is partially hidden by a heavily modified lip which has fragmented into a double, flap-like protrusion. The original description of the genus mentions the presence of supplementary openings in the central part of the apertural face (Loeblich \& Tappan, 1962; also Cushman, 1929). These openings are found in some specimens but are lacking in the large majority of them, including the type specimens. These openings may be due either to taphonomical effects, or may be linked to reproduction. I do not consider them to be primary and therefore disregard them as being of any use for descriptive and taxonomic purposes. The toothplate is an intricate piece of calcite, rather large and perforated by a number of holes, which contacts the septum not only at the foraminal lips, but also at the foraminal spines. The construction of the toothplate differs from the Bulimina-like toothplate in Reussella, but is rather similar to the one in Trimosina. The similarity of the toothplate morphology to the one in Sagrina raises disturbing questions as to which grounds to use for taxonomic decisions. It has become increasingly difficult to argue the relative merits of characteristics used to define supraspecific (and especially suprageneric) taxa.

The analogy in toothplate anatomy and the resemblance of the apertural face between Trimosina, Mimosina and Fijiella demonstrates affinities between these three genera extending beyond the more superficial resemblances of coiling and test shape. Fijiella can be regarded as the more primitive genus in this group: the aperture is not yet double, but the beginnings for it are present (witness the doubling of the apertural lip). Development is taken one step further with Trimosina, in which the aperture has become double, but with the lower one still very narrow; the toothplate is still a single plate, but the multiple attachment sites clearly show the increasing complexity. The pinnacle is reached with Mimosina, with two very prominent primary apertures and (especially) the convoluted toothplate. Therefore, the Trimosinidae are maintained and redefined to include Trimosina,
Mimosina and Fijiella.

The status of Compressigerina remains still somewhat uncertain because of the state of preservation of the specimens. However, the apertural neck is a very strong indication for uvigerine affinities, and, together with the habitus of the test being reminiscent of Angulogerina, sufficient arguments are available to reclassify it in the Uvigerinidae.

The majority of genera studied deviate substantially from the reussellid or even buliminid concept, i.e. they lack a toothplate, possess a very uncharacteristic apertural face and have a mixed seriality. I therefore propose to recognise these fundamental differences by introducing the superfamily Pavoninacea.

The genera herein revised in the Pavoninacea fall into two groups. On the one hand there is the group centred round Pavonina, including Finlayina, Bifarinella and to a lesser extent Valvobifarina. They are characterised by the distinctly compressed nature of the test with a marked tendency towards flabelliformity, and an apertural face which is very elongate. On the other hand there is the group centred round Chrysalidinella, including Cifellia and Orthocerina. This second group is characterised by uniseriality in the adult stage, the non-compressed chambers and the apical, multiple aperture.

Other genera to be included in the superfamily are already known to lack internal structures, such as Loxostoma, Aragonia and Bolivinella.

Earlier revisions removed some genera from the Buliminacea, i.e. Buliminella and Buliminoides (Revets, 1990a, b) and Tosaia (Nomura, 1985). The large number of genera herein removed favours the cause for a separate superfamily even more. It is intriguing to note that all forms in the Pavoninacea are eminently shallow water forms. Perhaps this may be a first indiction towards solving the mystery of the function of the toothplate.

A rethinking of the classification of the Buliminacea sensu lato, based on generic revisions has become urgent in order to restore stability and increase the understanding of this group.

\section{ACKNOWLEDGEMENTS}

I gratefully acknowledge the very kind and efficient collaboration of the curators of the different institutions, repositories of the material here studied, and colleagues for the generous donations of material: J.E. Whittaker, British Museum of Natural History, London; M.A. Buzas, Smithsonian Institution, Washington DC; P. Hallock-Muller, University of South Florida; M.-T. Vénec-Peyré, Muséum National d'Histoire Naturelle, Paris; F. Rögl, Naturhistorisches Museum Wien, Austria; P.R. Hoover, Palaeontological Research Institute, New York; B. Hayward, New Zealand Geological Survey, Lower Hutt; and H.J. Hansen, University of Copenhagen, Denmark. I thank J.E. Whittaker for the many SEM photographs of the specimens housed in the British Museum, and H.J. Hansen for the permission and assistance in using the SEM facilities of the University of Copenhagen.

Manuscript received June 1990

Manuscript accepted August 1990

\section{REFERENCES}

Acosta, J.T. 1940. Algunos Foraminíferos nuevos de las Costas Cubanas. Torreia, 5, $1-6$ 
Bermúdez, P.J. 1949. Tertiary smaller Foraminifera of the Dominican Republic Cushman Laboratory for Foraminiferal Research, Special Publication, 25, 322p.

Brady, H.B. 1881. Notes on some of the reticularian Rhizopoda of the Challenger Expedition, Part III. Quarterly Journal of Microscopical Science, new series, 21, $31-71$.

Brady, H.B. 1884. Report on the Foraminifera dredged by H.M.S. Challenger, during the years 1873-1876, in Reports on the Scientific Results of the Voyage of the H.M.S. Challenger during the years 1873-1876, Zoology, 9, 814p.

Brotzen, F. 1940. Flintrännans och Trindetlrännans Geologi. Arsbok Sveriges Geologiska Undersökning, 34, 1-33.

Brotzen, F. 1948. The Swedish Palaeocene and its foraminiferal fauna. Arsbok Sveriges Geologiska Undersökning, 42, 1-140

Cushman, J.A. 1927. An outline of a re-classification of the foraminifera. Contributions from the Cushman Laboratory for Foraminiferal Research, 3, 1 105.

Cushman, J.A. 1929. The genus Trimosina and its relationships to other genera of the Foraminifera. Journal of the Washington Academy of Sciences, 19, 155-159.

Cushman, J.A. 1933. Foraminifera, their classification and economic use. Cushman Laboratory for Foraminiferal Research, Special Publication, 4, 349p.

Cushman, J.A. 1937a. A monograph of the subfamily Virgulininae of the foraminiferal family Buliminidae. Cushman Laboratory for Foraminiferal Research, Special Publication, 9, xv $+228 \mathrm{p}$.

Cushman, J.A. 1937b. A monograph of the foraminiferal family Valvulinidae. Cushman Laboratory for Foraminiferal Research. Special Publication, 8, 210p.

Cushman, J.A. 1945. The species of the subfamily Reussellinae of the foraminiferal family Buliminidae. Contributions from the Cushman Laboratory for Foraminiferal Research, 21, 23-54.

Cushman, J.A. 1948. Foraminifera. Their Classification and economic use. Harvard University Press, 4th edition, 605p.

Cushman, J.A. \& Hanzawa, S. 1936. New genera and species of Foraminifera of the Late Tertiary of the Pacific. Contributions from the Cushman Laboratory for Foraminiferal Research, 12, 45-48

d'Orbigny, A. 1826. Tableau Méthodique de la classe des Céphalopodes. Annales des Sciences Naturelles, 7, 245-314.

d'Orbigny, A. 1839. Foraminifères. In Ramon de la Sagra, Histoire physique. politique et naturelle de l'ile de Cuba, Bertrand, Paris, xlviii $+224 \mathrm{p}$.

d'Orbigny, A. 1846. Foraminifères fossiles du Bassin Tertiaite de Vienne (Autriche). Gide, Paris, $312 \mathrm{p}$.

Eimer, G.H.T. \& Fickert, C. 1899 . Die Artbildung und Verwandtschaft bei den Foraminiferen. Entwurf einer natürlichen Eintheilung derselben. Zeitschrift fïr Wissenschafiliche Zoologie. 65, 527-636.

Galloway, J.J. 1933. A Manual of Foraminifera. Principia Press, Bloomington, xxxi $+483 p$.

Galloway, J.J. \& Wissler, S.G. 1927. Pleistocene foraminifera from the Lomita Quarry, Palos Verdes Hills, California. Journal of Paleontology, 1, 35-87.

Gibson, T.G. 1987. Morphological changes and migrational history of the genus Tubulogenerina. Journal of Foraminiferal Re search, 17, 227-239.

Gibson, T.G 1989. Miocene evolution of Tubulogenerina in the Indo-Pacific and African Areas. Jownal of Foraminiferal Research, 19, 126-145.

Haekel. E. 1894. Systematische Phylogenie. Entwiuf eines natiolichen Sustems der Organismen auf Grund ihrer Stammesgeschichle. Theil I. Systematische Phvlogenie der Protisten und Pfanzen. Reimer,Berlin, $x v+400 \mathrm{p}$.

Haynes, J. 1981. Foraminifera. MacMillan. London. xii $+433 \mathrm{p}$.

Hayward, B.W. \& Morgans, H.E.G. 1981. Finlayina hornibrooki, a new foraminifer from the Oligocene of Oamaru, New Zealand. New Zealand Journal of Geolugy and Geophysic's, 24,439-441.

Heron-Allen, E. \& Earland. A. 1924. The Miocene Foraminifera of the "Filter Quarry", Moorabool River, Victoria, Australia. Iommal of the Royal Microscopical Society, 121-186.

Heron-Allen, E. \& Earland, A. 1930. The Foraminifera of the Plymouth district. Journat of the Royal Microscopical Society, 161-199.

Hofker, J. 1951. The Foraminifera of the Siboga Expedition. Part III. Ordo Dentata. subordines Protoforaminata, Biforaminata. Deuteroforaminata. Uitkomsten of Zoologisch. Botanisch, Oceanografisch en Geologisch Gebied, Momografie, IVa. $513 \mathrm{p}$.

Hofker, J. 1957. Foraminiferen der Oberkreide von Nordwestdeutschland und Holland. Beihefte zum Geologischen Jahrbuch, 27, 464p.

Jones, T.R. 1875. In Griffith, J.W. \& Henfrey, A. The Micrographic Dictionary.1. 316-320. Van Voorst, London. 3rd edition.

Le Calves, Y. 1977. Foraminifères de l'ile de Cuba-Tome 2. Cahiers de Micropaléontologie, 2. $131 \mathrm{p}$.

Loeblich, A.R. \& Tappan, H. 1962. Six new generic names in the Mycetozoida (Trichiidae) and the Foraminiferida (Fischerinidae, Buliminidae. Caucasinidac and Pleurostomellidae), and a redescription of Loxostomum (Loxostomidac, new family). Proceedings of the Biological Socicty of Washingtom. 75. 107-113.
Loeblich, A.R. \& Tappan, H. 1962. Suprageneric classification of the Rhinopoclea. Journal of Palaeontology, 35, 245-330.

Loeblich, A.R. \& Tappan, H. 1964. Sarcodina, chiefly "Thecamoebians" and Foraminiferida, In Moore, R.C. (ed.), Treatise on Invertebrate Paleontolog: Geological Society of America and University of Kansas Press, New York and Lawrence, KS. Part C, Protista 2, 2 vols, 900p.

Loeblich, A.R. \& Tappan, H. 1987. Foraminiferal Genera and their Classification. Van Nostrand Reinhold, New York. 2 vols, $x+970 p$, viii $+1069 p$.

Millett, F.W. 1900. Report on the Recent Foraminifera of the Malay Archipelago collected by Mr A. Durrand, F.R.M.S. - Part IX. Journal of the Royal Microscopical Society, 539-549.

Nomura, R. 1985. On the genus Tosaia (Foraminiferida) and its suprageneric classification. Journal of Paleontology, 59, 222-225.

Palmer. D.K. 1941a. Foraminifera of the Upper Oligocene Cojimar Formation of Cuba, Part 4. Memorias de la Sociedad Cubana de Historia Natural "Felipe Poey", 15, 181-200.

Palmer, D.K. 1941b. Foraminifera of the Upper Oligocene Cojimar Formation of Cuba, Part 5. Memorias de la Sociedad Cubana de Historia Natural "Felipe" Poey". 15, 281-306.

Parker, W.K. \& Jones, T.R. 1863. On the nomenclature of the foraminifera. Part X. The species enumerated by d'Orbigny in the "Annales des Sciences Naturelles" vol. vii, 1826. Annals and Maga-ine of Natural Histor, 12, 429-441.

Reuss, A.E. 1850. Neues Foraminiferen aus den Schichten des österreichischen Tertiärbeckens. Denkschriften der kaiserlichen Akademie der Wissenschaften. Mathematisch-Naturnissenschaftliche Klasse. 1, 365-390.

Revets. S.A. 1989. Structure and Comparative Anatomy of the Toothplate in the Buliminacea (Foraminiferida). Joumal of Micropalaeontology 8, 23-36.

Revets, S.A. 1990a. The genus Buliminoides Cushman. 1911. Jommal of Foraminiferal Research. 20.50-55

Revets, S.A. 1990b. The genus Buliminella Cushman, 1911. Journal of Foraminiferal Research, 20, 336-348.

Rögl, F. 1986. Some interesting types of agglutinated Foraminifera in the Collection of the Natural History Museum in Vienna, p.51 in Rögl, F. (ed.). Second International Workshop on Agg/utinated Foraminifera - Ahstracts. Program and Excusion Guide. Institute of Palaeontology, Unisersity of Vienma.

Saidova. Kh. M. 1975. Bentosnye Foraminifery Tikhogo Okeana. Institut Okeanologii Moskva, Akademiya Nauk SSSR, 3 vols.

Saidova, Kh. M. 1981. O sorromennom sostoyanii sistemy nadidoyk taksonon Kaynozoyskikh bentosnykh foraminifer. Instirut Okeanologii Moskva. Akademiya Nauk SSSR.

Schubert, R.J. 1908. Beiträge zu einer natürlichen Systematik der Foraminiferen. Nenes Jahrbuch für Mineralogie. Geologic und Paläontologie, Beitrage, 25. 232. 260.

Schwager, C. 1877. Quadro del proposto sistema di classificazione dei foraminiferi con guscio. Bolletino Reale Comitato Geologico d' ltalia. 8, 18-27.

Srinivasan, M.S. 1966. Descriptions of new species and notes on taxonomy of Foraminifera from the Upper Eocene and Lower Oligocene of New Zealand. Transactions of the Royal Society of Nen Zealand. Geology, 3. 231-256.

Uchio, T. 1952. Foraminiferal assemblages from Hachijo Island. Tokyo Prefecture. with descriptions of some new genera and species. Japanese Jounal of Geology and Geography, 22, 145-159. 